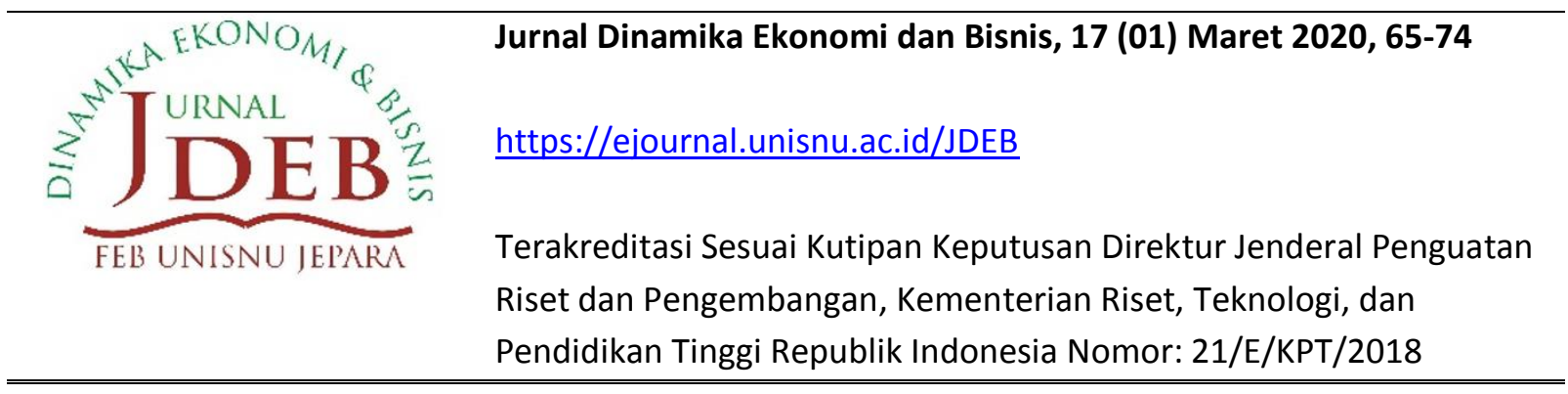

\title{
PENDAPATAN NON HALAL SEBAGAI SUMBER DANA KEBAJIKAN PADA BANK UMUM SYARIAH
}

\author{
Ernawati \\ Fakultas Ekonomi dan Bisnis, Universitas Halu Oleo \\ Email: ernawaty@uho.ac.id
}

\begin{abstract}
This study aims to determine the use of non-halal income in Islamic commercial banks as qardhul hasan funds. The research data are sourced from the results of the publication of Islamic banking statistics from the Financial Services Authority (OJK), and annual reports of Islamic commercial banks in 2018, with a sample of 10 banks. The data obtained are tabulated and further processed with percentages and diagrams. The research findings show that the non-halal income of Islamic commercial banks consists of interest income and penalty income. The income is not recognized as belonging to Islamic commercial banks but is treated as qardhul hasan funds and allocated for the benefit of social activities. The Contribution of non-halal income to the total qardhul hasan funds is quite high, or by 55.62 percent. Although these qardhul hasan funds are used for social purposes, they need to minimize and avoided, as BNIS's decision to eliminate the policy of payment penalties. On the other hand, needs to availability of wadiah product for depositing Islamic bank funds in conventional banks to eliminate interest revenue. This wadiah product is not based on interest rateson.
\end{abstract}

Keywords : Income, non-halal, penalty, interest, qardhul hasan funds

\begin{abstract}
Abstrak
Penelitian ini bertujuan untuk mengetahui pemanfaatan pendapatan non halal pada bank umum syariah sebagai dana kebajikan. Data penelitian bersumber dari hasil publikasi statistik perbankan syariah Otoritas Jasa Keuangan (OJK), dan laporan tahunan bank umum syariah tahun 2018, dengan sampel 10 (sepuluh) bank. Data yang diperoleh ditabulasi berdasarkan permasalahan yang dianalisis, dan diolah lebih lanjut dengan bantuan persentase dan grafik. Temuan penelitian menunjukkan bahwa sumber pendapatan non halal bank umum syariah terdiri dari pendapatan bunga, dan pendapatan denda/pinalti. Pendapatan tersebut tidak diakui sebagai milik bank umum syariah, namun diperlakukan sebagai dana kebajikan yang dialokasikan untuk kepentingan kegiatan sosial. Besarnya share pendapatan non halal terhadap total dana kebajikan cukup tinggi, atau sebesar 55,62 persen. Meskipun dana kebajikan ini digunakan untuk tujuan sosial, namun perlu terus diminimisasi bahkan dihindari, sebagaimana keputusan BNIS untuk menghilangkan kebijakan denda keterlambatan angsuran. Pada sisi lain, pendapatan jasa giro dapat dihindari melalui ketersediaan layanan khusus wadiah (titipan) bagi penempatan dana bank syariah pada bank konvensional. Produk wadiah ini tidak berbasis bunga maupun bagi hasil, namun berfungsi sebagai titipan.
\end{abstract}

Kata Kunci: Pendapatan, non halal, denda, jasa giro, dana kebajikan

Sitasi: Ernawati. (2020). Pendapatan Non Halal Sebagai Sumber Dana Kebajikan Pada Bank Umum Syariah, Jurnal Dinamika Ekonomi dan Bisnis, 17 (01) 2020, 65-74. 


\section{PENDAHULUAN}

Pendapatan non halal bagi merupakan pendapatan yang diperoleh dari sumber yang bertentangan dengan prinsip muamalah. Adapun prinsip khusus muamalah terdiri dari: (1) aktivitas yang diperintahkan seperti: objek transaksi halal, adanya keridhaan pihak-pihak yang bermualamah, dan amanah; (2) aktivitas terlarang seperti: riba, gharar, tadlis, dan larangan lainnya yang menyebabkan akad muamalah batal (Djamil, 2013). Sementara Adiwarman (2011) mengemukakan bahwa transaksi yang terlarang dalam Islam karena tiga faktor, yaitu: terlarang karena zat, terlarang karena bukan zat, dan tidak sah akadnya.

Dalam bidang keuangan, prinsip-prinsip syariah yang dilarang dalam operasional perbankan syariah adalah kegiatan yang mengandung unsur-unsur yang terlarang selain zatnya seperti transaksi yang mengandung unsur: maysir, gharar, dan riba. Maisir adalah memperoleh keuntungan dengan cara mudah tanpa harus bekerja keras, seperti berjudi dan mengundi nasib.

Ketika melakukan perjudian seseorang dihadapkan kondisi dapat untung maupun rugi secara abnormal. Suatu saat ketika seseorang beruntung ia mendapatkan keuntungan yang lebih besar ketimbang usaha yang dilakukannya. Sedangkan ketika tidak beruntung seseorang dapat mengalami kerugian yang sangat besar. Perjudian tidak sesuai dengan prinsip keadilan dan keseimbangan sehingga diharamkan dalam sistem keuangan Islam (OJK, 2020). Selanjutnya, transaksi gharar adalah transaksi yang mengandung ketidahjelasan baik dalam kuantitas, kualitas, maupun harga. Setiap transaksi yang masih belum jelas barangnya atau tidak berada dalam kuasanya atau di luar jangkauan termasuk jual beli gharar. Transaksi gharar terlarang dalam Islam, karena merupakan praktik pengambilan keuntungan secara bathil, sebagaimana Qs. Al-Baqarah ayat 188. Selanjutnya riba secara harfiyah adalah pertambahan, kelebihan, pertumbuhan atau peningkatan, sedangkan menurut istilah teknis, riba berarti pengambilan tambahan dari harta pokok atau modal secara bathil (OJK, 2020).

Pada praktiknya, hasil penelitian Harkaneri \& Reflisa (2018), mengungkapkan bahwa terdapat unsur riba dalam pendapatan bank syariah, sebagaimana tampak pada pendapatan non halal. Hal ini terungkap pula dari beberapa penelitian lainnya. Hartanto, Pramono, \& Purnamasari (2019) melakukan studi pendapatan non halal pada bank umum syariah dan unit usaha syariah dengan menggunakan data total. Sementara Muchlis dan Utomo (2018) melakukan studi pendapatan non halal dan dampaknya perspektif mikro dengan studi kasus Cabang BMI Kota Makassar. Studi mengenai pendapatan non halal juga telah dilakukan khsusnya dalam perspektif akuntansi sebagaimana Lenap (2019).

Studi ini mengkaji pendapatan non halal perbankan syariah sebagai sumber dana kebajikan. Studi ini juga mengungkap keterkaitan antara pendapatan non halal bank syariah kaitannya dengan penempatan dana bank syariah pada lembaga atau perbankan konvensional.

\section{METODE}

Jenis data penelitian yaitu data kuantitatif yang bersumber dari data sekunder hasil publikasi laporan tahunan bank umum syariah di Indonesia dan statistik perbankan syariah Otoritas Jasa Keuangan (OJK), tahun 2018. Berdasarkan ketersediaan data, terdapat 10 (sepuluh) bank umum syariah yang dijadikan sampel penelitian. Data sekunder yang dikumpulkan berupa laporan pendapatan non halal, jumlah dana yang ditempatkan pada 
lembaga keuangan konvensional oleh Bank Umum Syariah (BUS), dan laporan dana kebijikan. Data yang diperoleh kemudian ditabulasi berdasarkan permasalahan yang dianalisis, dan diolah lebih lanjut dengan bantuan persentase dan diagram.

\section{HASIL}

\section{Sumber Pendapatan Non Halal}

Perkembangan pendapatan non halal dari 10 bank umum syariah sebagaimana disajikan pada tabel 1 menunjukkan tren yang bervariasi. Peningkatan tertinggi dialami oleh BMS hampir dua kali lipat yang pada tahun 2017 sebesar 177 juta rupiah menjadi 353 juta rupiah. Peningkatan pendapatan non halal juga dialami oleh BRIS, BBS dan BA. Pada sisi lain, pendapatan non halal pada BNIS, BSM, BMI, BCAS, MBS, dan BTPNS justru pengalami penurunan. Penurunan tertinggi dialami oleh BNIS sebesar 95 persen. Penurunan ini dipicu oleh kebijakan BNIS untuk meniadakan denda dalam pengembalian pembiayaan. Berdasarkan keputusan Komite Kebijakan Risiko (KKR) No. 40 tanggal 22 Agustus 2016, BNIS menetapkan penghapusan denda tunggakan sehingga denda/sanksi atas tunggakan pembiayaan yang menjadi salah satu sumber dana kebajikan pada periode-periode sebelumnya, kini sudah ditiadakan.

Tabel 1. Pendapatan Non Halal Bank Umum Syariah Tahun 2017-2018

\begin{tabular}{|c|c|c|c|c|}
\hline No & Bank & $\begin{array}{c}2017 \\
\text { (juta rp) }\end{array}$ & $\begin{array}{c}2018 \\
\text { (juta rp) }\end{array}$ & $\begin{array}{c}\text { Perkembangan } \\
(\%)\end{array}$ \\
\hline 1 & BRIS & 803 & 1.073 & 33.62 \\
\hline 2 & BNIS & 1.395 & 60 & -95.70 \\
\hline 3 & BSM & 24.854 & 23.437 & -5.70 \\
\hline 4 & BCAS & 613 & 405 & -33.93 \\
\hline 5 & BMI & 882 & 649 & -26.4 \\
\hline 6 & BMS & 177 & 353 & 99.44 \\
\hline 7 & MBS & 167 & 12 & -92.81 \\
\hline 8 & BBS & 690 & 761 & 10.29 \\
\hline 9 & BTPNS & 602 & 235 & -60.96 \\
\hline 10 & BA & 568 & 772 & 35.92 \\
\hline
\end{tabular}

Secara rinci, tabel 2 menyajikan sumber pendapatan non halal Bank Umum Syariah di Indonesia tahun 2017 dan 2018, yang menunjukkan bahwa sumber pendapatan non halal terdiri dari pendapatan bunga, dan pendapatan denda/pinalti. Pendapatan non halal BSM bersumber dari: (1) Penalty, yakni dana yang berasal dari denda keterlambatan pembayaran angsuran.; (2) pendapatan bunga atau jasa giro yang diterima bank dari penempatan pada bank konvensional; dan (3) dana yang berasal dari komisi, fee, atau pendapatan dalam bentuk lainnya dari rekanan bank selain pendapatan yang berhak diterima sesuai dengan ketentuan manajemen. 
Tabel 2 Jumlah Pendapatan Denda dan Jasa Giro (Bunga) Pada Bank Umum Syariah Tahun 2018

\begin{tabular}{llrrrr}
\hline \multirow{2}{*}{ No } & Nama Bank & \multicolumn{2}{c}{$\mathbf{2 0 1 7}$} & \multicolumn{2}{c}{$\mathbf{2 0 1 8}$} \\
\cline { 3 - 6 } & & Denda & $\begin{array}{c}\text { Bunga } \\
\text { (juta rp) }\end{array}$ & $\begin{array}{c}\text { Denda } \\
\text { (juta rp) }\end{array}$ & $\begin{array}{c}\text { Bunga } \\
\text { (juta rp) }\end{array}$ \\
\hline 1 & BRIS & 270 & 533 & 190 & 883 \\
2 & BNIS & n.a & 1395 & 0 & 60 \\
3 & BSM & 24.778 & 76 & 22.809 & 628 \\
4 & BCAS & 599 & 14 & 378 & 27 \\
5 & BMI & 17 & 865 & 16 & 633 \\
6 & BMS & 265 & 1 & $n . a$ & 353 \\
7 & MBS & 151 & 16 & 1 & 11 \\
8 & BBS & 458 & 232 & 209 & 552 \\
9 & BTPNS & 52 & 550 & 94 & 141 \\
10 & BA & 190 & 378 & 489 & 283 \\
\hline \multicolumn{2}{l}{ Sumber: Laporan Tahunan masing-masing BUS, 2018 (diolah) }
\end{tabular}

Pendapatan denda memiliki komposisi terbesar dalam pendapatan non halal pada BSM dan BCAS. Sementara bagi MBS share pendapatan non halal terbesar untuk tahun 2017 bersumber dari pendapatan denda, sementara tahun 2018 dari bunga. Tren ini juga dialami oleh BBS yang pada tahun 2018 mengalami peningkatan pada pendapatan bunga, dan penurunan pada pendapatan denxda. Sebaliknya dengan BA mengalami penurunan pangsa pada pendapatan bunga dan peningkatan pada pendapatan denda.

Pada BRIS, BNI, dan BTPNS memiliki pangsa terbesar pendapatan non halal pada tahun 2017 dan 2018 secara konsisten bersumber dari jasa giro. Pendapatan bunga dari jasa giro diperoleh bank umum syariah sebagai reward dari penempatan dana pada bank lain berbasis bunga. Penempatan pada bank lain, dikelompokkan dalam penempatan pada Bank Indonesia, dan penempatan pada bank lain. Penempatan pada bank Indonesia dalam bentuk giro, SBIS (sertifikat bank Indonesia Syariah), FASBIS (Fasilitas Simpanan Bank Indonesia Syariah) dan lainnya. Sementara penempatan pada bank lain, terdiri dari Giro, Deposito, Setoran Jaminan, dan lainnya.

Pada tahun 2018, komposisi penempatan dana Bank Umum Syariah pada bank lain, sebagaimana disajikan pada Gambar 1 menunjukkan bahwa komposisi terbesar penempatan dana bank syariah yaitu pada FASBIS, selanjutnya giro, kemudian SBIS.

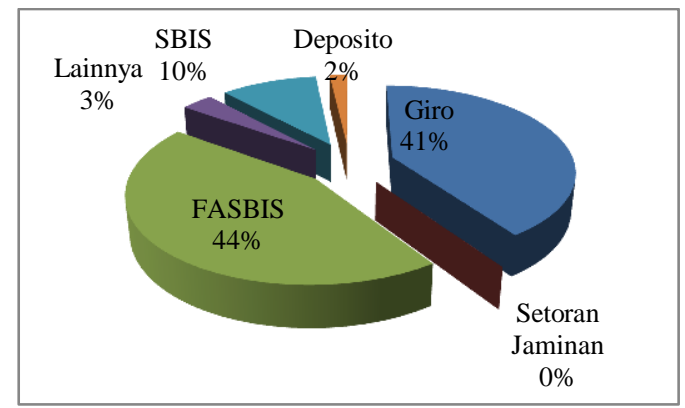

Gambar 1 Komposisi Penempatan Dana Bank Umum Syariah Tahun 2018

Sumber: OJK (2019), diolah

Besarnya penempatan dana pada bank lain (selain BI) yang dilakukan oleh Bank Umum Syariah di Indonesia terdiri dari penempatan dana pada pihak ketiga, dan penempatan dana 
pada bank berelasi. Pihak-pihak berelasi terjadi karena hubungan kepemilikan dan/atau kepengurusan. Pihak-pihak berelasi terdiri dari Badan Usaha Milik Negara dan Anak Perusahaannya, dewan komisaris, direksi dan karyawan kunci berdasarkan PSAK No.7 (Revisi 2010). Pada tahun 2017, pihak berelasi BSM adalah anak perusahaan BUMN (perbankan, pegadaian, asuransi, rumah sakit, penerbangan, manufaktur), perusahaan BUMD (bank BPD) dan karyawan kunci. Sementara pihak perelasi BCAS hanya BCA Konvensional, sementara pihak berelasi BRIS yaitu BRI dan Bank Mandiri

\section{Dana Kebajikan dan Pemanfatannya}

Tabel 3 menyajikan kontribusi pendapatan non halal terhadap dana kebajikan pada Bank Umum Syariah di Indonesia, yang menunjukkan bahwa dana kebajikan bersumber dari pendapatan non halal dan dana sosial lainnya, seperti: zakat, infaq dan sedekah serta sumbangan lainnya.

Tabel 3 Kontribusi Dana Kebajikan Bank Umum Syariah Tahun 2018

\begin{tabular}{llrr}
\hline \multirow{2}{*}{ No } & \multirow{2}{*}{ Nama Bank } & \multicolumn{2}{c}{ Kontribusi (\%) } \\
\cline { 3 - 4 } & & Pendapatan Non Halal & Sumber Lainnya \\
\hline 1 & BRIS & 17.98 & 82.02 \\
2 & BNIS & 14.42 & 85.58 \\
3 & BSM & 97.76 & 2.24 \\
4 & BCAS & 98.78 & 1.22 \\
5 & BMI & 100.00 & 0.00 \\
6 & BMS & 100.00 & 0.00 \\
7 & MBS & 100.00 & 0.00 \\
8 & BBS & 99.93 & 0.07 \\
9 & BTPNS & 100.00 & 0.00 \\
10 & BA & 4.51 & 95.49 \\
\hline Rata-rata & 55.62 & 44.38 \\
\hline
\end{tabular}

Sumber: Laporan Tahunan masing-masing BUS, 2018 (diolah)

Tabel 3 menyajikan secara rata-rata, dari 10 bank umum syariah yang dijadikan sampel, kontribusi pendapatan non halal dalam dana kebajikan sebesar 55,62\% atau lebih besar dibanding kontribusi dana sosial lainnya. Bahkan terdapat 4 (empat) bank yang memiliki kontribusi 100\%, yaitu: BMI, BMS, MBS, dan BTPNS.

Dana kebajikan yang diterima oleh lembaga keuangan syariah ini disalurkan dalam bentuk: (1) Bantuan fisik dan non fisik; bantuan kondisi darurat; pemberdayaan bidang ekonomi, pendidikan, kesehatan, keagamaan/ dakwah, seni-budaya, sosial/ kemasyarakatan; CSR; dan lain-lain yang relevan sesuai fatwa/opini Dewan Pengawas Syariah. Pada BSM, penggunaan pendapatan non halal BSM disalurkan melalui LAZNAS BSM, sebesat 21,349 milyar pada tahun 2017. Dari jumlah tersebut, sebanyak 100 juta diperuntukkan bantuan kendaraan operasional kampus Universita Kutai, 911 juta diberikan untuk amil dan sebanyak 20,338 milyar dalokasikan dalam kegiatan sosial kemanusiaan BSM mengalir berkah.

Sementara pada BMS, jumlah pendapatan non halal pada tahun 2017, telah teralokasikan seluruhnya untuk tahun tersebut. Bantuk alokasi dana non halal yaitu kegiatan sosial, diantaranya: pembangunan mesjid, pendidikan, kesehatan, kemanusiaan, kegiatan keagamaan, kendaraan operasional kesehatan, panti asuhan, wakaf, THR Karyayan MUI. 
Dengan demikian, pendapatan non halal tersebut dialokasikan dalam bentuk kegiatan sosial. Pengalokasian pendapatan non halal dilakukan secara langsung maupun tidak langsung. Tabel 4 menyajikan lembaga yang diserahi pendistribusian dana kebajikan merupakan BAZNAS dan LAZ (Lembaga Amil Zakat), baik LAZ afiliasi bank syariah maupun bukan afiliasi.

Tabel 4 Lembaga Alokasi Pendapatan Dana Kebajikan Bank Umum Syariah

\begin{tabular}{cll}
\hline No & Nama Bank & Lembaga Alokasi \\
\hline 1 & BRIS & BAZNAS, Yayasan Baitul mal BRI, dll \\
2 & BNIS & Yayasan Hasanah Titik \\
3 & BSM & LAZNAS BSM \\
4 & BMS & Disalurkan secara langsung \\
5 & BVS & BAZNAS \\
Sumber: & Laporan Tahunan 2018 masing-masing bank
\end{tabular}

\section{PEMBAHASAN}

Temuan penelitian memunjukkan bahwa sumber pendapatan non halal bank umum syariah yaitu: denda dan pendapatan bunga atau jasa giro yang diterima dari penempatan pada bank konvensional. Denda atas keterlambatan pembayaran angsuran merupakan salah satu jenis riba jahiliyyah. Riba jahiliyyah, adalah hutang dibayar lebih dari pokoknya karena si peminjam tidak mampu membayar hutangnya pada waktu yang ditetapkan. Sementara jasa giro yang diperoleh termasuk riba nasi'ah, yaitu riba yang ditimbulkan akibat tukar menukar barang yang sejenis maupun tidak sejenis yang pembayarannya disyaratkan lebih dengan diakhiri atau dilambatkan oleh yang meminjam (Antonio, 2001).

Denda tidak diperbolehkan, berbeda halnya dengan ganti rugi yang dibolehkan secara syariat sesuai dengan Fatwa Dewan Syariah Nasional No. 43/DSN-MUI/VIII/2004. Pada ketentuan umum fatwa tersebut, terdapat 4 (empat) kondisi diterapkannya gantirugi, yaitu: (1). jika terdapat pihak yang dengan sengaja atau karena kelalaian melakukan sesuatu yang menyimpang dari ketentuan akad dan menimbulkan kerugian pada pihak lain; (2). Kerugian yang dapat dikenakan sebagaimana dimaksud dalam no.1 adalah kerugian riil. (3). Kerugian riil adalah biaya-biaya riil yang dikeluarkan dalam rangka penagihan hak yang seharusnya dibayarkan, dan (4). Besarnya ganti rugi sesuai dengan nilai kerugian riil dan bukan kerugian yang diperkirakan akan terjadi.

Pengambilan riba hanya boleh dalam kondisi darurat, sebagaimana kondisi darurat diblolehkannya seorang muslim untuk memakan 'sesuatu' yang diharamkan, seperti yang terkandung dalam Qs. Al Baqarah ayat: 173. Dengan demikian umat Islam tidak boleh bermuamalah dengan bank yang memakai system bunga, kecuali dalam keadaan darurat atau terpaksa (OJK, 2020).

Kebolehan akan dilakukannya hal yang mengandung keharaman disebabkan oleh adanya unsur kedaruratan didalamnya. Menurut Zuhaily (1995) dalam terminologi juris, darurat merupakan keadaan sulit yang dihadapi oleh manusia yang dapat mengancam jiwa, akal, harta dan kehormatannya sehingga dibolehkan baginya (melakukan) hal yang haram, atau meninggalkan kewajiban atau bahkan mengundur waktunya guna menghindari terjadi kemudaratan lebih besar bagi dirinya dalam koridor yang dibenarkan secara syariat (Mubarak, 2017). 
Pada sisi lain, temuan penelitian menunjukkan bahwa kontribusi pendapatan non halal terhadap dana kebajikan cukup besar, atau secara rata-rata pada tahun 2018 sebesar 55,62 persen. Temuan penelitian menunjukkan bahwa pendapatan non halal pada bank umum syariah dialokasikan dalam bentuk kegiatan sosial, baik disalurkan baik secara langsung maupun melalui lembaga sosial. Beberapa pandangan ulama mengenai pemanfaatan barang yang haram sebagimana dikutib dari DSN (2018) salah satunya adalah pendapat Al Ghazali.

“ bahwa apabila terdapat harta haram pada seseorang, dan ia ingin bertaubat serta melepaskan diri dari harta haram tersebut, maka jika pemilik harta tersebut diketahui wajib baginya menyerahkan harta tersebut kepadanya atau wakilnya. Jika pemiliknya sudah meninggal dunia, wajib diberikan kepada ahli warisnya, dan jika tidak diketahui pemiliknya dan tidak ada harapan (sulit sekali) untuk mengetahuinya, maka sebaiknya ia menggunakan harta tersebut untuk kemaslahatan kaum muslim, seperti membangun jembatan, sarana pendidikan Islam, masjid, jalan menuju ke Makkah dan semisalnya, yang menjadi kebaikan bersama bagi kaum muslim. Apabila tidak, maka sedekakanlah kepada seorang fakir atau lebih" (Al-Ghazali).

Fatwa DSN MUI No. 123/DSN-MUI/XI/2018 tentang ketentuan penggunaan dana TBDSP (tidak boleh diakui sebagai pendapatan), dipaparkan bahwa: dana TBDSP wajib digunakan dan disalurkan secara langsung untuk kemaslahatan umat Islam dan kepentingan umum yang tidak bertentangan dengan prinsip syariah. Bentuk-bentuk penyaluran Dana TBDSP yang dibolehkan adalah bantuan/sumbangan secara langsung untuk: (a) penanggulangan korban bencana, (b) sarana penunjang lembaga pendidikan Islam, (c) masjid/ musholla dan penunjangnya, (d) pembangunan fasilitas umum yang berdampak sosial, (e) sosialisasi, edukasi, dan literasi ekonomi, keuangan dan bisnis syariah untuk masyarakat umum, (f) beasiswa untuk siswa/mahasiswa berprestasi dan atau kurang mampu, (g) kegiatan produktif bagi dhuafa, (h) fakir-miskin, (i) kegiatan sosial lain yang tidak bertentangan dengan prinsip syariah. (3) Dana TBDSP boleh disalurkan secara langsung oleh LKS (lembaga keuangan syariah), LBS (lembaga bisnis syariah), dan LPS (lembaga perekonomian syariah) dan/atau melalui lembaga sosial. Dana TBDSP tidak boleh imanfaatkan untuk kepentingan LKS, LBS dan LPS antara lain dalam bentuk: (a) promosi produk maupun iklan perusahaan; (b) pendidikan dan pelatihan untuk karyawan; (c) pembayaran pajak, zakat, dan wakaf; (d) pembayaran/ pelunasan tunggakan nasabah; (e) kegiatan yang bertentangan dengan prinsip syariah.

Alokasi dana kebajikan pada kegiatan sosial, tampaknya memberi manfaat kepada masyarakat umum dalam bentuk peningkatan kualitas sumber daya manusia, kesejahteraan masyarakat dan modal sosial. Namun hal ini tidaklah berarti bahwa sumber dana kebajikan yang berupa pendapatan non halal dimaksimumkan, sebab penerimaan pendapatan dari non halal merupakan perkara darurat, sehingga perlu dihindari. Mengutamakan tujuan maslahat dan mengabaikan syariat tidak dibenarkan. Sebab salah satu prinsip Islam tentang halal-haram yaitu bahwa 'niat yang baik tidak dapat menghalalkan yang haram' (Qardhawi, 2007).

Pada sisi lain satu kaidah kuliyah (global) dalam hukum Islam adalah: "menghindari yang mengandung kerusakan lebih diutamakan dibanding sekedar mendatangkan maslahat, karena prinsip hukum Islam adalah mendatangkan kemaslahatan dan sekaligus menolak kemadlaratan (Wijayanti \& Meftahudin, 2018). 
Pendapatan non halal bank syariah, yang salah satunya jasa giro yang diterima dari bank konvensional dapat disiasati dengan adanya kerjasama produk keuangan bank konvensioanal khusus terkait dengan penempatan dana lembaga keuangan syariah yang berbasis titipan, atau simpanan wadiah. Simpanan wadiah dalam konteks lembaga keuangan terdiri dari dua, yaitu wadiah yad-amanah dan wadiah yad-dhamanah. Wadiah yad-amanah yaitu penerima titipan tidak boleh memanfaatkan barang yang dititipkan tetapi tetap menjaga sesuai kelaziman. Karena penerima titipan menjada amanah tersebut dan tidak memanfaatkannya, maka pihak penerima titipan dapat membebankan biaya kepada penitip.

Pada sisi lain, dana yang dititipkan dengan perjanjian wadi'ah yad-dhamanah dapat memanfaatkan dana tersebut, dan keuntungannya menjadi hak penerima titipan. Namun sebagai imbalan kepada pemilik dana dapat diberikan semacam insentif berupa bonus yang tidak diisyaratkan sebelumnya. Dengan demikian, guna menjaga keberlangsungan jaringan atau relasi perbankan syariah terhadap lembaga keuangan konvensional, namun tetap berada dalam koridor syariat, diperlukan suatu mekanisme aturan dimana lembaga keuangan konvensional memiliki produk khusus wadiah bagi simpanan/ penempatan dana yang dimiliki oleh bank syariah.

\section{PENUTUP}

Bank umum syariah masih menerapkan sistem denda dalam atas keterlambatan angsuran, namun terdapat bank umum syariah yang telah menghapuskan sistem denda tersebut, yaitu BNIS. Pada sisi lain, terdapat jasa giro yang diterima oleh bank sebagai dampak penempatan dana pada lembaga konvensional yang berbasis bunga. Temuan ini mengimplikasikan akan dibutuhkannya produk berbasisi titipan atau wadiah khusus untuk dana yang ditempatkan bank syariah pada bank konvensional. Dimana dana yang ditempatkan hanya sebagai titipan bank syariah, karena bagaimanapun jasa giro yang diterima bank syariah tidak dapat diakui sebagai milik bank tersebut, dan hanya ditempatkan sebagai dana kebajikan. Sebab secara fiqih adalah lebih utama menghindari kerusakan, dibanding memperoleh manfaat.

Studi ini memiliki beberapa keterbatasan, khususnya tidak mengkaji mekanisme perbankan syariah dalam menentukan kebijakan denda, serta keterbatasan metode penelitian dalam mengungkap korelasi antara penempatan dana bank pada bank konvensional dengan pendapatan jasa giro yang diterima. Diharapkan peneliti selanjutnya mendalami aspek-aspek keterbatasan dalam penelitian ini.

\section{DAFTAR PUSTAKA}

Adiwarman A. Karim. (2011) Bank islam Analisis Fiqih dan Keuangan, Cet IV, Jakarta: PT. Raja Grafindo Persada

Antonio , Muhammad Syafie I. (2001). Bank Syariah Dari Teori ke Praktik, Cet I, Jakarta: Gema Insani

Al Qardhawi, Yusuf. 2007. Fiqh Al Zakah. Jakarta : Pustaka Nasiona 
BA. (2019). Laporan tahunan 2018. Tersedia pada: www.bankaceh.co.id/ wpcontent/uploads/2019/04/ LAPORAN-TAHUNAN-BANK-ACEH-2018.pdf. Diunduh pada 20 Januari 2020.

BBS. (2019). Laporan tahunan 2018. Tersedia pada: www.syariahbukopin. co.id/public/uploads/report/AR_BSB_2018_Web_compressed.pdf. Diunduh pada 20 Januari 2020.

BCAS. (2019). Laporan tahunan 2018. Tersedia pada: www.bcasyariah. co.id/media/2019/04/BCAS\%20AR\%202018\%20\%20Webversion1.pdf. Diunduh pada 20 Januari 2020.

BNIS. (2019). Laporan tahunan 2018. Tersedia pada: www.bnisyariah. co.id/Portals/1/BNISyariah/Perusahaan/Hubungan\%20Investor/Laporan\%20Tahunan/A R\%202018/AR\%20BNIS\%202018-compressed.pdf. Diunduh pada 20 Januari 2020.

BRIS. (2019). Laporan tahunan 2018. Tersedia pada: https://www. brisyariah.co.id/images/upload/reports/c8b2561a533fa87d44300219e0308eb2_Laporan _Tahunan.pdf. Diunduh pada 20 Januari 2020.

BSM. (2019). Laporan tahunan 2018. Tersedia pada: https://www.mandiri syariah.co.id/assets/pdf/annualreport/AR_2018_Mandiri_Syariah_22102019.pdf.

Diunduh pada 20 Januari 2020.

BSM. (2018). Laporan tahunan 2018. https://www.mandirisyariah.co.id/assets/pdf/annualreport/Annual\%20 Report\%20Bank\%20Syariah\%20Mandiri\%202017.pdf. Tersedia pada: Diunduh pada 20 Januari 2020.

BMI. (2019). Laporan tahunan 2018. Tersedia pada: www.bankmuamalat. co.id/uploads/hubungan_investor/1_laporan-tahunan-2018.pdf. Diunduh pada 20 Januari 2020.

BMS. (2019). Laporan tahunan 2018. Tersedia pada: $\underline{\text { www.megasyariah }}$ .co.id/files/reports/annual/ARBMS-2018.pdf. Diunduh pada 20 Januari 2020.

BTPNS. (2019). Laporan tahunan 2018. Tersedia pada: http://btpnsyariah. com/documents/20182/21371/2017+Eng.pdf/d1f7de0e-f7da-4572-8dcc5f3787b498ee?version=1.0. Diunduh pada 20 Januari 2020.

MBS. (2019). Laporan tahunan 2018. Tersedia pada: http://maybank syariah.co.id/report/20190430114702_maybanksyariah_annual_report.pdf. Diunduh pada 20 Januari 2020.

Djamil, F. (2013) Hukum Ekonomi Islam: Sejarah, Teori, dan Konsep, Jakarta: Sinar Grafika.

Harkaneri \& Reflisa, Hana. (2018). Pendapatan Non Halal Sebagai Sumber Dan Penggunaan Qardhul Hasan Dalam Perspektif Islam, Syarikat : Jurnal Rumpun Ekonomi Syariah, $1(2), 102-110$ 
Hartanto, R., Pramono, I.P., \& Purnamasari, P. (2019). Analisis Pendapatan Non Halal Perbankan Syariah Di Indonesia: Sumber Dan Penggunaannya. Falah: Jurnal Ekonomi Syariah, 4(2), 159-171

Ikatan Akuntansi Indonesia. 2010. PSAK 7 (Revisi 2010) Tentang Pengungkapan PihakPihak Berelasi. Jakarta : IAI

Lenap, Indria Puspitasari. (2019). Pengungkapan Pendapatan Non Halal : PSAK 109 VS Praktik, Jurnal Aplikasi Akuntansi, 3(2), 94 -116. https://doi.org/10.29303/ jaa. v3i2.45.

Mubarrak, Husni. (2017). Penalaran Istiṣlāḥ̄ dalam Kajian Fikih Kontemporer: Studi Kasus Fatwa Hukum Imunisasi di Aceh. AHKAM Jurnal Ilmu Syariah. 17(1), 199-222.

Muchlis, Saiful dan Utomo, Husain Soleh (2018). Kajian Pendapatan Non Halal Dan Dampak Penggunaannya Terhadap Reputasi Dan Kepercayaan Nasabah Perbankan Syariah (Study Empiris Pada Bank Muamalat) ,JRAK: Jurnal Riset Akuntansi \& Komputerisasi Akuntansi 9(1), 75-101.

MUI. (2004). Fatwa Dewan Syariah Nasional No. 43/DSN-MUI/VIII/2004. Tentang. Ganti Rugi (Ta'widh). Tersedia pada: https://drive.google.com/file/d/0BxTlINihFyzWDFxQVdPQmxfRU0/vi ew. Diunduh pada 6 Maret 2020.

MUI. (2018). Fatwa DSN MUI No. 123/DSN-MUI/XI/2018 Tentang Penggunaan dana yang Tidak Boleh Diakui Sebagai Pendapatan Bagi Lembaga Keuangan Syariah, Lembaga Bisnis Syariah, dan Lembaga Perekonomian Syariah. Jakarta: MUI, 08 November 2018M

OJK. 2019. Statistik Perbankan Syariah Desember 2018. Tersedia pada: https://ojk.go.id/id/kanal/syariah/data-dan -statistik/ statistik -perbankan syariah/Documents/ Pages/ Statistik-Perbankan-Syariah---Desember2018/SPS\%20Desember\%202018.pdf. Diunduh 20 Februari 2020.

OJK. 2020. Prinsip dan Konsep Dasar Perbankan Syariah Tersedia pada: https://ojk.go.id/id/kanal/syariah/tentang-syariah/Pages/Prinsip-dan-Konsep-PB-

Syariah.aspx. Diunduh 5 Februari 2020.

Qardhawi, Yusuf. 2007. Halal Haram Dalam Islam. Jakarta: Era Intermedia

Wijayanti, Ratna \& Meftahudin. (2018). Kaidah Fiqh dan Ushul Fiqh Tentang Produk Halal, Metode Istinbath dan Ijtihad dalam menetapkan Hukum Produk Halal. International Journal Ihya' 'Ulum Al-Din, 20(2), 241-268.

Zuhaili, Wahbah, Naẓariyyah Darūrat Syar'iyyah, Beirut: Maktabah Risālah, 1985 _Ushūl Fiqh al-Islāmīy, Beirut: Dar el-Fikr, 1996 